\title{
Risk factors for stakeholders in renewable energy investments
}

Vidmantas Jankauskas ${ }^{1}$,

Paulius Rudzkis ${ }^{1}$,

\section{Adomas Kanopka ${ }^{2}$}

${ }^{1}$ Vilnius Gediminas

Technical University,

Sauletekio Ave. 11,

LT-10223 Vilnius, Lithuania

E-mail:vidmantas.jankauskas@vgtu.lt; paulius.rudzkis@gmail.com

${ }^{2}$ Mykolas Romeris University,

Ateities St. 20,

LT-08303 Vilnius, Lithuania

E-mail:adomas.kanopka@gmail.com
Modern economic development is based on innovative ideas and new investments. The better resources are deployed in investment projects, the higher the level of innovation and return for the society. On the other hand, both the efficiency of investment activities and the pace of economic growth are, to a great extent, conditioned by the quality of the system of selecting investment projects, which correspond to the existing and changing circumstances of economic functioning. The paper aims to identify and assess risk factors for renewable energy investment projects from stakeholders' perspective. To achieve this objective, the risk analysis methods were examined and factors affecting the investment risk of renewable energy sources and their types were identified and analysed from the point of view of the public sector, funder and investor. The qualitative expert assessment method was used to evaluate the risk factors.

Key words: risk management, qualitative risk analysis, renewable energy industry

\section{INTRODUCTION}

The last quarter of the twentieth century saw two global trends of the energy industry: 1) the ever increasing need for electricity and 2) the trends of environmental degradation and climate change associated with the incineration of fossil fuel. These two trends have called for a need for new capital investments in electricity production.
The growing need for electricity, the associated challenges and new development trends resulted in a situation where more than two decades ago many countries started, and have continued to date, reforms of the electricity sector to boost competition. Privatisation and liberalisation of the electricity sector is aimed to create a competitive environment within the sector that ensures better 
efficiency and benefits for the end consumers. The European Commission, the Organisation of Economic Cooperation and Development (OECD), the World Bank and the European Bank for Reconstruction and Development (EBRD) were supporters of this unique reform of the electricity industry.

Historically, liberalisation of the electricity sector started from the creation of a wholesale market of spot transactions (settlements). Now, after more than twenty years from when liberalisation of the electricity market started, reforms still continue. As the overview of the EU liberalisation market shows, the reform was not equally effective in all countries. Accelerating climate change prompted while newly developed and upgraded energy technologies formed a basis for expanding the use of renewable energy sources. Although technology innovations allowed to realistically bring down electricity production costs between 1990 and 2005 [1], production of energy from renewable sources caused substantial increases of production prices in many energy sectors. The ambitious energy policy goals of individual countries (to double or even triple production of energy from renewable sources) caused by changes in the energy policy raised tension among investors in other sources of energy (e. g. nuclear energy) because these investment projects have a long return on the investment period ( $15-30$ years).

According to the World Bank [2], many reforms of the energy sector have faced similar challenges: to identify funding methodologies for new investments with a view to improving their efficiency and to raise operating efficiency. Each country has to address the related practical issues, including public-private partnership, individually.

The key instrument that promotes economic development is implementation of innovative highperformance investment projects. On the other hand, both efficiency of the investment activity and the pace of economic growth are, to a great extent, conditioned by the quality of the system of selecting investment projects, which corresponds to the existing and changing circumstances of economic functioning. Decisions based on the methodology of assessing innovative investment projects affect not only the interests of stakeholders, but also national interests because the aggregate of individual decisions eventually shapes the speed and direction of a nation's economic development.

One of the key objectives for governments in attracting private investments in the electricity sector is minimising the investment risk. Risk minimisation takes various forms, such as national energy planning, evaluation of resources, market forecasting, surveillance of the securities market, evaluation and supervision of projects and assistance in providing access to capital and funding.

Promoting investments in renewable energy is an even more challenging task as it also involves identifying reasoned environmental standards. Development of renewable energy addresses two interrelated objectives: 1) establishing the public interest that would be promoted or protected; 2 ) identifying means and ways to achieve the defined goals.

Evaluation of renewable energy projects is encumbered by their linkage with a specific location and by their dependence on the features of a particular locality. Given today's development stage of engineering and technology, implementation of renewable energy systems is often inefficient in terms of cost, and yet the increasingly priced and exhausted traditional sources have called for a more intensive use of renewable sources of energy. On the other hand, scientific and technological progress has upgraded technologies of using renewable energy sources, thus improving their competitive advantage over fossil energy sources. Research shows that the cost of energy produced using a specific technology has direct negative relationship to experience, while experience is directly related to the quantity of introduced technologies [3].

Therefore, both the business and the public sector are interested in having a trustworthy methodology, which is capable of assessing the cost-efficiency and risks of renewable energy sources. It should be noted that existing methodologies are not completely adapted to the specific nature of introducing renewable energy sources.

The object of this research is the analysis of risk of renewable energy (RE) investment projects. The main purpose of this research is to de- 
velop and apply methods of assessing the risk of (RE) investment projects. The objectives of the research are the following:

- To carry out a risk concept analysis;

- To review the existing investment risk analysis methods;

- To identify factors that significantly affect the uncertainty and risk of RE investment projects;

- To evaluate the importance and cost significance of the identified factors.

Research methods used in the paper are as follows: comparative literature analysis, methods to assess the risk of investment projects, future insights methods, the expert assessment method.

\section{RISK AND UNCERTAINTY}

Practical application of financial and economic analysis methods to investment projects requires a broad data range including financial, technological, legal, environmental and other types of information. A substantial part of this information is of prognostic nature and relates to the future, which always has a high degree of uncertainty. This type of information can never be complete and accurate because the values are of a probabilistic nature and can be described within certain limits only. Similarly, the efficiency of the project, which depends on the conditions of implementation, also has a probabilistic nature. It is for this particular reason that substantial focus is given both to the financial and economic analysis and to efficiency assessment in the context of risk and uncertainty [4-6]. As the literature analysis shows, despite the numerous theoretical and practical considerations in this field, the variety of investment areas and goals has prevented creating a single solution to this problem. Investment decisions always involve some kind of risk. The risk of implementing investment projects (IP) is mostly affected by indefinite future events, which may have a negative impact on the financial value of investment projects. The problem here is that we cannot say with complete accuracy either what outcome we will obtain in the future or what the level of the potential costs will be.

Evaluation of the efficiency of investment projects using cost / benefit analysis methods rests on the assumption that the exact values from each period of the cash flow generated in the project implementation process are known. Whereas in the real world this is an exception rather than a rule. Therefore one has to forecast not only how the structure of cash flow develops with time, but also the probabilities of its potential deviations. The potential deviation of the outcomes of financial transactions from the most probable values shows the degree of risk. This means that risk assessment is a very important and vital part of analysing the efficiency of investment projects.

The key feature of risk is that it relates to the uncertainty of the future and that an investment decision has to be made under incompletely defined conditions of the heterogeneous environment. Hence there are two concepts: future-related uncertainty and uncertainty-related risk. The difference between the two concepts is that the uncertainty of the future is objective and we can neither change nor control it.

When assessing risk, we can formulate the criterion of making an investment decision as that depending on two complex variables: IP efficiency $=f\left(\right.$ benefit $\left._{i}, r_{i}\right)$, where $\mathrm{i}$ is a stakeholder and $r$ is a risk factor. When 'uncertainty' of the situation occurs, it is impossible to determine the cost and benefit with complete accuracy because they are still to be obtained in the future.

As the literature analysis shows, it is almost universally accepted that uncertainty and risk are inseparable from the decision-making process, but there is no absolute agreement on the definitions of uncertainty and risk [7-11].

Neither are risk and uncertainty equivalent from the traditional economic point of view. Yet the term 'uncertainty' is sometimes not strictly separated from risk, particularly when decision-making is related to an unknown future or when the future is known, but cannot be measured. From the classical point of view risk affects the decisions where the effects of actions are probabilistic and have a known probability distribution [12].

At present, two basic approaches to uncertainty and risk exist:

1. Risk results from uncertainty. Uncertainty in this case is perceived as incomplete or inaccurate information about the values of different 
parameters in the future, which results from incomplete or inaccurate information about the environment of implementing an investment decision.

2. Situational risk occurs for the reason that the emergence of some events has probabilistic nature, which can be evaluated using probabilistic methods.

The uncertainties of the future develop under the influence of a number of different factors:

- Uncertainty in time results from the fact that the meaning and significance of many factors in the future cannot be accurately defined;

- Uncertainty of the market cycle, i. e. the exact point estimates of the market parameters are unknown;

- Behaviour of stakeholders and their conflicts of interest also contribute to the general level of uncertainty, etc.

A combination of these factors creates a range of various levels of uncertainty. Uncertainty, as an inherent precondition for implementing investment projects, is one of the important components of complex economic phenomena. Uncertainties come in large numbers in the global free market, which has no stringent regulation.

Uncertainty is of great significance to the situation on the market. The economic behaviour of investors on the market is determined by their choice and by the activity conducted under risk conditions, which is limited by legislation. Each participant of market relations acts without having success guarantees and without knowing the exact and unambiguously defined values of parameters such as the number of market players, accessibility of resources at fixed prices, the purchasing power of consumers, demand, etc.

Stakeholders may have extremely different estimations of the set of risk sources and their impact. In a general case, the spectrum of energy risk sources is very wide [13]: financial risk, operating risk, regulatory risk, technological risk, market risk, legislative risk, taxation risk, availability risk. Due to a high number of risk factors the outcome of potential business activity becomes an accidental value. Just like every accidental value, it has its distribution function and parameters.

\section{RISK ANALYSIS METHODS FOR INVESTMENT PROJECTS}

Research literature offers various definitions of risk analysis and management methods, but many distinguish two components of risk: risk analysis and risk assessment [14]. The principal aim of risk analysis is to identify the specific risk levels by revealing the link between the likelihood of occurrence of a specific event and the consequences of that occurrence [15]. International risk management standards provide general risk management schemes, which distinguish a number of key steps [15-16]:

- Defining the company's strategic goals, risk acceptance and tolerance;

- Riskassessment, which includes risk identification, risk analysis and risk evaluation;

- Risk minimisation.

The aim of risk assessment is to estimate and provide data on the appropriateness of implementing an investment project and to propose measures to minimise potential financial loss. The general aim of risk assessment can be broken down into a number of components:

- identifying a set of risk factors and causes of risk (uncertainties) for specific projects;

- analysing the consequences of realisation of the identified hypothetical risks and estimating their monetary equivalent;

- proposing measures to minimise loss.

Selecting a method for analysis is one of the critical stages of risk analysis. Risk and uncertainties can be assessed using two types of methods: quantitative and qualitative. These methods supplement rather than replace each other while their integrated application ensures a more accurate risk assessment. Depending on the analysed situation, qualitative techniques suit better in some cases while quantitative techniques in others. When combined for the purpose of analysis, qualitative and quantitative methods produce a mixed type. Quantitative analysis is used to determine and classify the factors, areas and types of risk, to identify their causes, to assess potential negative effects and to measure and minimise potential loss $[4,6,17]$. Where qualitative or mixed methods are used for risk analysis, the final outcome has a quantitative 
expression, i. e. in addition to identification and description of different risks, analysis of causes of risk, evaluation of their potential effects and proposals for minimisation of identified risks, the qualitative analysis of an investment project includes a monetary expression of measures to minimise risk. Reliability of the qualitative variables is enhanced by quantitative structuring (weighted) methods, which assign respective values (weights) to the variables.

Selection of analysis methods depends on the level of detail of the analysis performed [14, 18]. In the case of a simplified risk analysis priority is given to qualitative risk assessment methods. For this purpose group expert assessment methods are often used. Risk assessment employs standard scales, e. g. a Likert scale, a semantic differential scale, etc. The general methodology of quantitative research breaks down into three consistent phases:

- identification of the characteristic risks of the project in question and description of the causes and factors that affect the individual risks;

- analysis and cost assessment of the potential effects of risks;

- identification and analysis of anti-risk measures and their cost assessment.

Standard risk analysis is more formalised and applies both qualitative and quantitative analysis methods: coarse risk analysis, HAZOP (hazard and operability study), failure modes effect analysis, risk matrix. The most complicated one is the model-based risk analysis, where priority is given to quantitative and mixed risk analysis methods: probability analysis, the decision tree method, the scenario method, etc.

To summarise, the following basic groups of risk analysis methods can be pointed out: the probability analysis, the expert assessment method, the analogy method, the margin level indicator analysis, the sensitivity analysis, the scenario method and simulation (the Monte Carlo method).

\section{RISK ASSESSMENT OF RE INVESTMENT PROJECTS USING QUALITATIVE ANALYSIS METHODS}

As mentioned above, risk is mostly related to the uncertainty of the future, so its assessment can rely on future insight methods. Growing global uncertainty results in a high risk of non-stationarity of trends, hence subjective probabilistic prediction of future events is of tremendous value. The insight methods are applied in studies of potential changes and potential processes as well as in the fields of technology and social systems [19]. Analysis of literature and practical applications shows that predictions of very distant future insights turn out to be inaccurate and mistakes in predicting critical events are not rare. Furthermore, a more exhaustive methodological substantiation of the insight methods is missing.

Literature devoted to both research and practical applications offers discussions on methods applied to insights. Selection of methods that can be applied to insights depends on a number of factors: analysis of the external and internal environment, intuition, available experience, and sometimes even lack of experience.

The main purpose of a qualitative risk analysis is to identify a high-, average- or low-significance risk of the analysed investment project and to prepare information for other stages of risk assessment, i. e. the risk evaluation. A study conducted in 2011 [20] showed that the most important risks for RE were financial (76\%), political and regulatory (62\%) and weather-related (66 per cent of respondents from the wind energy field) whereas a broad list of factors can be found in, for instance, [21].

As mentioned above, the concept and level of risk can differ significantly depending on the stakeholders. For instance, in long-term public-private partnership projects, the risks of the two sectors are different $[22,23]$.

RE projects normally involve three stakeholders: the public sector (the state), the funder and the investor. Therefore this research examines each identified risk from the point of view of these three stakeholders:

1. Risk from the public sector (the state) point of view: since in many cases $\mathrm{RE}$ is not competitive on the market, investment risk must be minimised in order to promote the use of RE and attract investment. So over the recent years the EU Member States have introduced support schemes (RE standards), which aim to attract investors by reducing the investment risk. The risk of the public sector is affected by political change, the deteriorating natural environment and the outcomes 
of investment projects that are unacceptable to the public.

2. From a funder's point of view, the risk of an investment project is primarily related to the legal regulation of the country's economic processes and administrative governance. Changes in the political situation and innovations may stop or render impossible the implementation of an investment project both at its development stage and at its funding and implementation stages. Since from the point of view of a funder (commercial banks and other financial institutions) reliable long-term financing is the most critical crediting condition, it is important for the funder that state-developed support schemes have the lowest possible political and legal risks.

3. The investor's point of view: investments in the renewable energy sector are risky and hard to get a return on. For the investor, both the risk created by the public sector and the funder's risk is important, but he is also exposed to other risks directly related to the implementation of the project. Here the critical factors include reliability of subcontractors, efficient management, a suitable quality management system, cost price stability and compliance with standards and norms.

In Lithuania, eight groups of RE risk factors were distinguished as significant in terms of assessing and minimising the investment risk: development and construction, political environment, opinion, market, regulatory, financial, weather-related and environmental. These groups of risk factors include from 1 to 7 factors, 25 factors in total (Table 1).

The expert assessment employed 6 experts with between 4 and 12 years of experience with RE projects: a head of a credit institution, a risk assessor of a credit institution, three professional investors working with RE projects and an analyst of energy projects. The experts rated the risk factors on a scale of 11 points: 0 - no risk, 10 - very high risk. The five high-risk factors are listed in Table 1.

From the investors' point of view, the experts shared opinions: Kendall's coefficient of concordance $W=0.33$, observed significance level $p=0.022$. The experts also shared similar opinions regarding the funder's risk: $W=0.36$, $p=0.009$. At the same time two experts had dif- ferent opinions on the risk of the public sector. Once the assessments of these two experts had been excluded from the research, it turned out that the opinions of the rest of the experts were similar: $W=0.57$, observed significance level $p=0.016$.

As the results of the expert assessment show (Table 2), due to different aims and interests of stakeholders their RE investment risk factors differ significantly.

\section{INVESTOR'S AND FUNDER'S RISK ANALYSIS}

The expert assessment showed that the highest investor's risk is related to the delay in project delivery, the highest funder's risk is related to losses due to investor's bankruptcy and the highest public sector risk is related to changes in public opinion. Estimating the public sector risk requires continuous monitoring of the public sphere, tracking of surveys and assessment of change trends and in it is not analysed in this paper. The highest risks of an investor and funder are sufficiently clear and their loss functions can be identified. An example of wind generated energy shall be used estimating impacts of certain risks.

The risk related to delays in project delivery can be assessed from two perspectives: first, delays entail additional costs, second, there is a probability that the project will not be delivered in time, i. e. it will hobble at some stage indefinitely. In both cases, the function of losses relates to the amount of investment, which means that the project should be divided in stages and the investments and timeframe of each stage should be assessed individually.

The duration of completing a wind farm from the acquisition of land to commissioning is around 18 months (Fig. 1). However, a survey of experts showed that project developers often encounter delays and a project may take up to 45 months to complete on average. Given the maximum likely delay at each stage of the project, the overall project duration may even rise to 79 months. The largest deviations from the plan occur during the preparation of the detailed plan and participation in an auction, while the construction stage progresses mostly to schedule. 
Table 1. RE risk types and their description

\begin{tabular}{|c|c|}
\hline Risk type & Description of risk \\
\hline \multirow[t]{5}{*}{$\begin{array}{c}\text { Development and construction (risk during design } \\
\text { and implementation caused by intermediaries } \\
\text { and subcontractors; the risk can be } \\
\text { regulated with contracts) }\end{array}$} & $\begin{array}{l}\text { 1. Shortage of information } \\
\text { about technical (operating) } \\
\text { characteristics of installations }\end{array}$ \\
\hline & $\begin{array}{l}\text { 2. Insufficient information about } \\
\text { environmental characteristics } \\
\text { (speed of wind, solar intensity, etc.) }\end{array}$ \\
\hline & $\begin{array}{l}\text { 3. Large differences in technology } \\
\text { reliability depending on manufacturers' } \\
\text { quality control }\end{array}$ \\
\hline & 4. Delay in project delivery \\
\hline & 5. Poor quality of work \\
\hline \multirow[t]{3}{*}{ Political environment } & $\begin{array}{l}\text { 6. Changes in the subsidy policy } \\
\text { that affects business profitability }\end{array}$ \\
\hline & $\begin{array}{l}\text { 7. External changes (EU, global) } \\
\text { that cause distinct changes in } \\
\text { the national economy }\end{array}$ \\
\hline & $\begin{array}{l}\text { 8. External changes that cause } \\
\text { political and field-specific or } \\
\text { macroeconomic instability }\end{array}$ \\
\hline Opinions & $\begin{array}{l}\text { 9. Changes in public opinion, } \\
\text { lobbying of stakeholders }\end{array}$ \\
\hline
\end{tabular}

Market (risk resulting from

changes on the market

10. Operating

where the product is sold)

\begin{tabular}{|c|c|}
\hline & 11. Demand fluctuations \\
\hline & $\begin{array}{l}\text { 12. Very rapid technology } \\
\text { development and related change } \\
\text { of price for installations }\end{array}$ \\
\hline & 13. Drop of prices in the energy market \\
\hline & $\begin{array}{l}\text { 14. Risk of bankruptcy } \\
\text { during the contract }\end{array}$ \\
\hline \multirow[t]{2}{*}{$\begin{array}{l}\text { Regulatory (project's external } \\
\text { risk caused by governmental } \\
\text { or other official authorities) }\end{array}$} & $\begin{array}{l}\text { 15. Changes in the renewable } \\
\text { energy policy }\end{array}$ \\
\hline & 16. Specific regulatory changes \\
\hline \multirow[t]{7}{*}{ Financial risks } & 17. Reduction of financial support \\
\hline & $\begin{array}{l}\text { 18. Availability of financial } \\
\text { support for the project }\end{array}$ \\
\hline & $\begin{array}{l}\text { 19. Availability of bank } \\
\text { financing for the project }\end{array}$ \\
\hline & $\begin{array}{l}\text { 20. Inflation, changes } \\
\text { in currency prices }\end{array}$ \\
\hline & 21. Breaches of contracts \\
\hline & 22. Breaches of borrowing contracts \\
\hline & 23. Taxation changes \\
\hline Weather-related & $\begin{array}{l}\text { 24. Reduction of produced } \\
\text { energy depending on } \\
\text { the shortage of wind or sun }\end{array}$ \\
\hline Environmental & $\begin{array}{l}\text { 25. Responsibility for } \\
\text { environmental damage }\end{array}$ \\
\hline
\end{tabular}


Ta ble 2. Five key risk factors of stakeholders listed in the order of importance

\begin{tabular}{|c|c|c|c|}
\hline $\begin{array}{c}\text { Serial } \\
\text { No. }\end{array}$ & Investor's risk & Funder's risk & Public sector risk \\
\hline 1. & Delay in project delivery & $\begin{array}{l}\text { Risk of bankruptcy during } \\
\text { the contract }\end{array}$ & $\begin{array}{c}\text { Changes in public opinion, } \\
\text { lobbying of stakeholders }\end{array}$ \\
\hline 2. & $\begin{array}{l}\text { Availability of bank financing } \\
\text { for the project }\end{array}$ & $\begin{array}{l}\text { Changes in the subsidy } \\
\text { policy that affects } \\
\text { business profitability }\end{array}$ & Demand fluctuations \\
\hline 3. & $\begin{array}{l}\text { Specific regulatory } \\
\text { changes }\end{array}$ & Delay in project delivery & $\begin{array}{c}\text { Responsibility for } \\
\text { environmental damage }\end{array}$ \\
\hline 4. & $\begin{array}{c}\text { Changes in the subsidy } \\
\text { policy that affects business } \\
\text { profitability }\end{array}$ & $\begin{array}{l}\text { Insufficient information } \\
\text { about technical (operating) } \\
\text { characteristics of installations }\end{array}$ & $\begin{array}{l}\text { Very rapid technology } \\
\text { development and } \\
\text { related change of } \\
\text { price for installations }\end{array}$ \\
\hline 5. & $\begin{array}{l}\text { External changes } \\
\text { (EU, global) that cause } \\
\text { distinct changes in } \\
\text { the national economy }\end{array}$ & $\begin{array}{l}\text { Changes in public } \\
\text { opinion, lobbying of } \\
\text { stakeholders }\end{array}$ & $\begin{array}{l}\text { Drop of prices in } \\
\text { the energy market }\end{array}$ \\
\hline
\end{tabular}

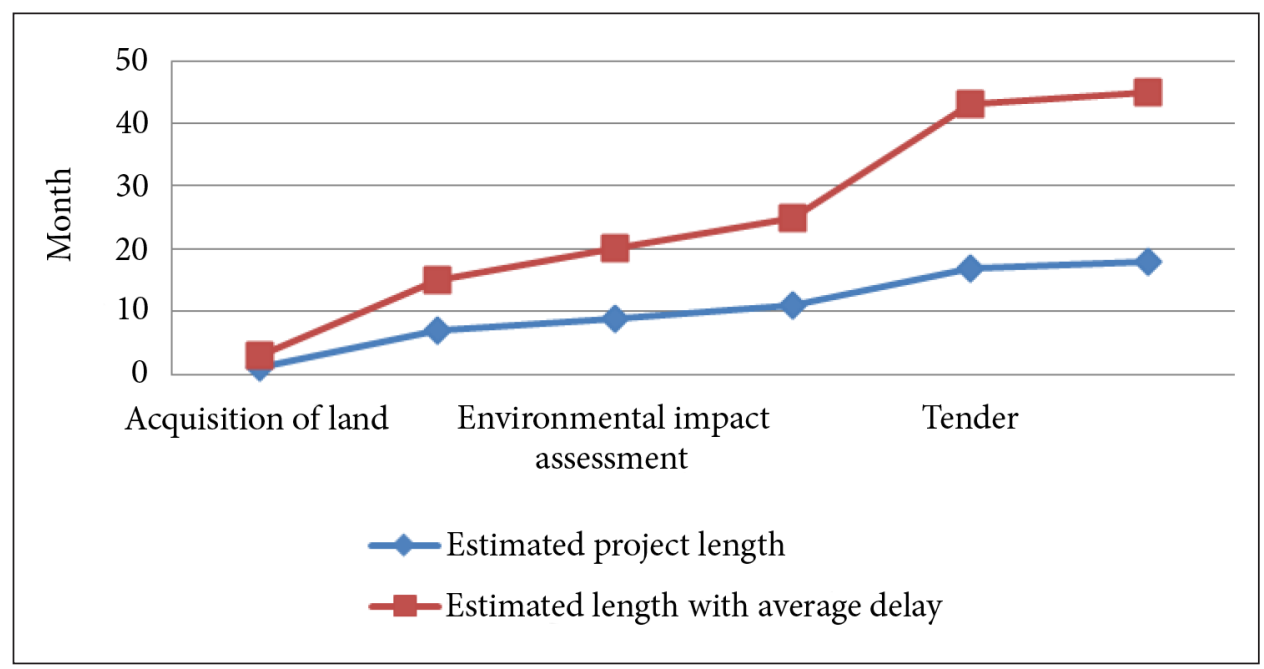

Fig. 1. Project implementation stages and implementation timeframe

When a project falls behind the schedule, it entails both direct and indirect costs. Capital costs account for the largest share of direct costs and indirect costs can be defined as the loss of income. Indirect costs can be measured as a function of capital costs and not received cash flows due to delay:

$$
L C_{\text {indirect }}=\sum_{i=1+T}^{n} \frac{\left(E G^{*} P-B P\right)}{(1+l)^{i}}, \quad i=1,2 . . n
$$

where $L C$ is indirect costs, $T$ is the planned duration of project implementation, $i$ is the delay month, $n$ is the total delay in months, $E G$ is the average amount of electricity generated monthly, $P$ is the buying-up price of electricity, $B P$ is payments to the bank and $l$ is the monthly discount rate.

In wind farm development projects, the share of equity capital usually stands at around $20 \%$. Moreover, the funder agrees to provide funding only after a successful tender, i. e. the funder usually agrees to finance the construction of wind farms only and refuses to finance preparatory stages. However, the need for investment is relatively weak before the construction and makes up a mere $4 \%$ which nevertheless accounts for about $20 \%$ of equity capital.

On average, $1 \mathrm{~kW}$ of installed power generates about $0.174 \mathrm{MWh}$ of electricity per month 
[24], the buying-in price stands at around 72 EUR/MWh and monthly payments to the bank should make up about $10.42 \mathrm{EUR} / \mathrm{kW}$. As of discount rate of $5 \%$, the indirect costs of an average delay calculated according to Formula 1 would make up to $115 \mathrm{EUR} / \mathrm{kW}$ and $244 \mathrm{EUR} /$ $\mathrm{kW}$ at the maximal delay.

Several factors must be taken into account when measuring direct costs such as the project stage, amount of investment and capital structure at the specific project stage. Therefore, direct costs can be defined as the amount of extra costs arising at the specific project stage:

$$
L C_{\text {direct }}=\sum_{i=1}^{n} \tau_{i} * I n v_{i} * W A C C, \quad i=1,2 . . n,
$$

where $L C_{\text {direct }}$ is direct costs, $i$ is the project stage, $\tau_{i}$ is the delay at stage $i, I n v_{i}$ is accumulated investments at stage $i$ and WACC is weighted average capital costs.

On average, project costs before the start of construction of generators stand at around $58.5 \mathrm{EUR} / \mathrm{kW}$, which makes up about $18 \%$ of total equity capital demand (Fig. 2). In case of an average delay, the costs may rise to $67.5 \mathrm{EUR} / \mathrm{kW}$ or increase by over $15 \%$. In case of a maximum delay, these costs may go up to $80.5 \mathrm{EUR} / \mathrm{kW}$ or grow by $37 \%$. Such an increase in costs would be relatively small and would account for 3\% and 7\% of equity capital costs, respectively.

If we sum up direct and indirect costs based on the average, the delay total loss of the project owner is at $124.6 \mathrm{EUR} / \mathrm{kW}$ what makes around $39 \%$ of equity while the maximal delay causes a loss $266.3 \mathrm{EUR} / \mathrm{kW}$ that is up to $82 \%$ of equity.

Looking at the situation from the funder's perspective, the main risk is related to bankruptcy or insolvency of a special purpose vehicle. Key evaluation aspects used by the funder to measure client's solvency are as follows: (a) the ability to cover the credit from operating income and the ratio between this income and bank credit; (b) the ratio between the pledged property and issued guarantees and the outstanding loan at each stage of credit.

In energy projects, operating income can be estimated quite easily where countries adopt a subsidising policy and use higher energy buyingin prices if we exclude any changes in the subsidy procedures which may affect the profitability of projects. According to the Bank of Lithuania, the average annual interest rate of $4.0 \%$ was the average rate applicable to euro loans issued to non-financial corporations for a period of more than five years in the period 2004-2013. Considering investment as $20 \%$ equity and $80 \%$ twen-

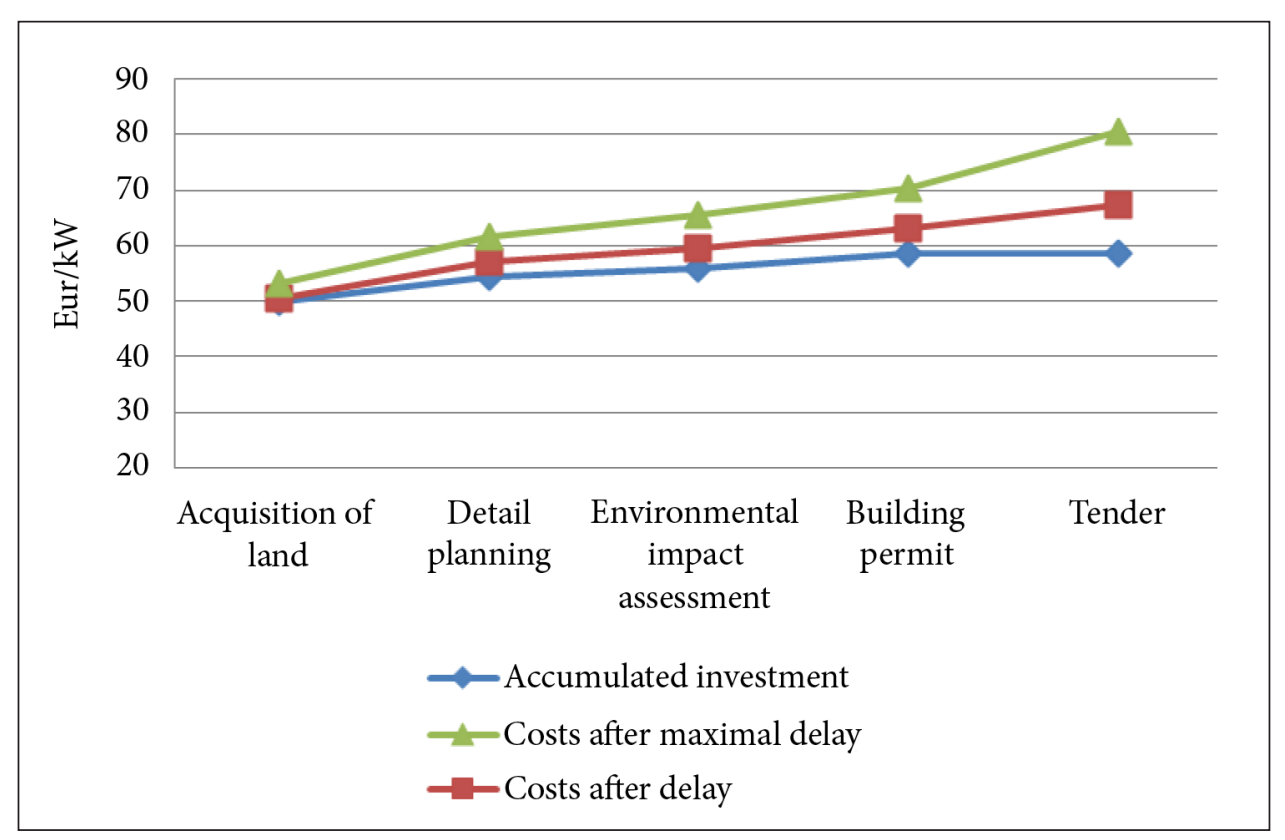

Fig. 2. Direct costs caused by project delays 


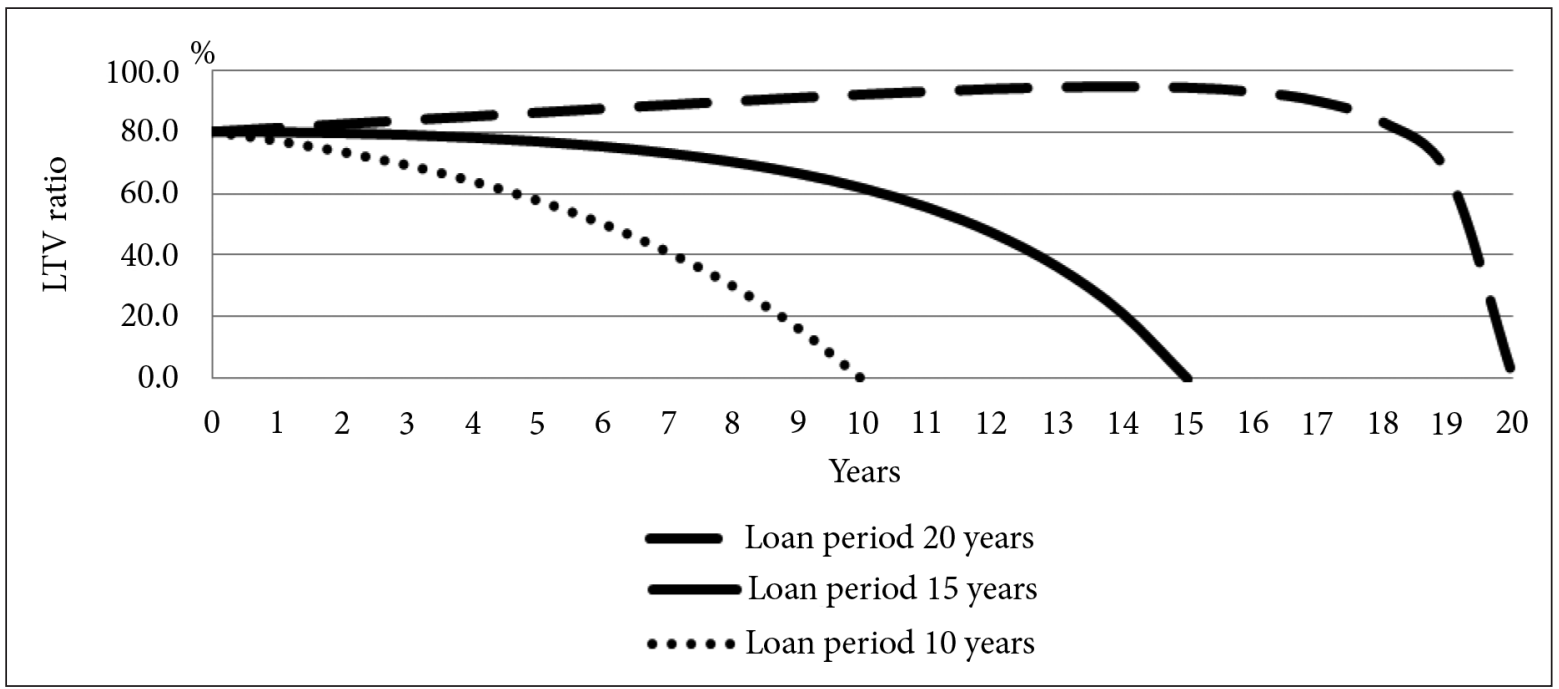

Fig. 3. Loan-to-value change in time at different period loans

ty-year loan, approximate annual payment with interest is $91.8 \mathrm{EUR} / \mathrm{kW}$ while income should be around 150 EUR $/ \mathrm{kW}$. Probably one of the main criteria considering loan intensity and payment rate is loan-to-value ratio or LTV. It is important to make sure LTV ratio does not get any higher than it is at the beginning of the loan.

If conditions of the loan are as mentioned above, LTV ratio slightly increases in time and after fourteen year reaching $94.6 \%$ starts to decrease. Such payment conditions are inappropriate for the investor and it is likely the investor will require a significant increase of payments. On the other hand, if the loan period is decreased to ten years and the investment structure is the same, most likely the annual payment will make 153.87 EUR/kW what is slightly higher than the annual income. Such conditions are infeasible for the project owner.

To sum up, the conditions the investor will offer and the project owner will have to take are fifteen year loan with annual payment of 112.25 EUR/ $\mathrm{kW}$ (considering that optimal average is fifteen years and six months), at such payment LTV ratio never gets above $80 \%$.

\section{CONCLUSIONS}

1. Evaluation of the efficiency of investment projects using cost / benefit analysis methods rests on the assumption that the exact values from each period of the cash flow generated in the project implementation process are known. This is an exception rather than a rule in the real world. Therefore one has to forecast not only how the structure of cash flow develops with time but also the probabilities of its potential deviations. This means that risk assessment is a very important and vital part of IP efficiency analysis.

2. Because investment risk is mostly related to the uncertainty of the future, it can be assessed using future insight methods. Selection of methods that can be applied to assess risk depends on a number of factors: analysis of the external and internal environment, intuition and available experience. Quantitative and qualitative methods are used to assess risk and uncertainties. These methods supplement each other while their integrated application ensures a more accurate risk assessment.

3. In RE projects three stakeholders are distinguished: the public sector (the state), the funder and the investor. Through adapting the expert assessment method to assess RE project risk, the list of the original risk factors was updated and the risk factors were assessed by relevance to the stakeholders. The analysis showed that of the five examined key risk factors within each group only three were relevant to more than one stakeholder: delay in project delivery; changes in the subsidy policy that affects business profitability; changes in the public opinion and lobbying of stakeholders.

4. Project owner's analysis has shown that direct loss due to project delay can amount to 
$22 \mathrm{EUR} / \mathrm{kW}$ what makes around $1.5 \%$ of the total investment and the demand for equity can be as high as additional $7 \%$. Indirect loss can be evaluated $244 \mathrm{EUR} / \mathrm{kW}$ or $73 \%$ of equity.

5. Investors analysis has shown that long term loans are not that suitable for such projects as the maximal lending period is fifteen years and six months otherwise the loan-to-value ratio gets outside acceptable boundaries. And the optimal loan period is fifteen years.

Received 27 February 2014 Accepted 26 May 2014

\section{References}

1. Fouquet R., Pearso P. J. G. Seven centuries of energy services: the price and use of light in the United Kingdom (1300-2000). Energy Journal. 2006. Vol. 27(1). P. 139-177.

2. World Bank. Public and Private Sector Roles in the Supply of Electricity Services. 2004. http:// siteresources.worldbank.org/INTENERGY/ Publications/20269078/Public_and_Private_ Roles_in_Electricity_Supply.pdf

3. Junginger M., Faaij A., Turkenburg W. C. Global experience curves for wind farms. Energy Policy. 2005. Vol. 33(2). P. 133-150.

4. Smidt S., Bierman H. Capital Budgeting Decision: Economic Analysis of Investment Projects. Pearson Education POD, 1992.

5. Kohli K. N. Economic Analysis of Investment Projects: A Practical Approach. Published for the Asian Development Bank. Oxford University Press, 1993.

6. Kurowski L., Sussman D. Investment Project Design: A Guide to Financial and Economic Analysis with Constraints. Wiley Finance, 2011.

7. Alessandri T. M., Ford D. N., Lander D. M., Leggio K. B., Taylor M. Managing risk and uncertainty in complex capital projects. Quarterly Review of Economics and Finance. 2004. Vol. 44(50). P. 751-767.

8. Alvarez S. A., Barney J. B. How do entrepreneurs organize firms under conditions of uncertainty. Journal of Management. 2005. Vol. 31(5). P. 776793.

9. Buckley A. Multinational Finance. 4th edition. England: Prentice Hall, 2000.
10. Lipshitz R., Strauss O. Coping with uncertainty. Organizational Behaviour and Human Decision Processes. 1997. Vol. 69(2). P. 149-163.

11. Miller K. D. Risk and rationality in entrepreneurial processes. Strategic Entrepreneurship Journal. 2007. Vol. 1(1-2). P. 57-74.

12. Knight F. H. Risk, Uncertainty, and Profit. New York: Houghton and Mifflin, 1921.

13. Meulbroek L. Total strategies for company-wide risk control: In: Mastering Risk (Vol. 3). London: Financial Times Mastering, 2000.

14. Avent T. Risk Analysis. Assessing Uncertainties beyond Expected Values and Probabilities. New Jersey: John Wiley \& Sons, Inc, 2008.

15. ISO 31000. Risk Management - Principles and Guidelines. 2009. http://www.iso.org/iso/catalogue_detail?csnumber $=43170$

16. COSO. Enterprise Risk Management - Integrated Framework. 2004. www.theiia.org/iia/download. cfm?file $=9229$.

17. Frame J. D. Managing Risk in Organizations. A Guide for Managers. Washington: Jossey-Bass, 2003.

18. Tamošiūnienè R., Šidlauskas S., Trumpaitè I. The multicriteria evaluation method of the effectiveness of the investment projects. Business: Theory and Practice. 2006. Vol. 7(4). P. 203-212.

19. Burinskienė M., Rudzkienè V. Future insights, scenarios and expert method application in sustainable territorial planning. Technological and economic development of economy. Baltic Journal on Sustainability. 2009. Vol. 15(1). P. 10-25.

20. Managing the Risk in Renewable Energy. A Report from the Economist Intelligence Unit Sponsored by Siss Re. 2011. http://www.altran.de/fileadmin/

21. Cleijne H., Ruijgrok VW. Modeling Risks of Renewable Energy Investments. Report of the project "Deriving Optimal Promotion Strategies for Increasing the Share of RES-E in a Dynamic European Electricity Market". European Communities, Energie, 2004.

22. Jones L. R. Return on investment analysis: Applying a private sector approach to the public sector. Prime Journal of Business Administration and Management. 2012. Vol. 2(1). P. 426-435. 
23. Weber Ch. Quantification of Political Risk in Energy Foresight: A Methods Overview. EWL Working Paper No. 1. 2010.

24. Rudzkis P., Macijauskas L. Attractiveness evaluation of investment in wind energy projects. Business in XXI Century. 2012. Vol. 4(3). P. 250255.

Vidmantas Jankauskas, Paulius Rudzkis, Adomas Kanopka

\section{INVESTICIJŲ İ ATSINAUJINANČIŲ IŠTEKLIŲ ENERGETIKĄ SUINTERESUOTŲJŲ ŠALIŲ RIZIKOS VEIKSNIAI}

Santrauka

Šiuolaikinis ekonomikos vystymas grindžiamas inovatyviomis idejomis ir naujomis investicijomis. Kuo geriau diegiant investicinius projektus yra išdèstomi ištekliai, kuo aukštesnis inovacijų lygis, tuo didesnę grąžą gauna visuomenè. Savo ruožtu, ir investicinès veiklos efektyvumą, ir ekonomikos augimo tempus didele dalimi lemia investicinių projektų atrankos sistemos kokybe், atitinkanti esančias ir kintančias ekonomikos funkcionavimo aplinkybes. Straipsnio tikslas - atsinaujinančių išteklių energetikos investicinių projektų rizikos veiksnių identifikavimas ir vertinimas suinteresuotųjų šalių aspektu. Sprendžiant ši uždavinị išnagrinèti rizikos analizès metodai, išskirti atsinaujinančių energijos šaltinių investavimo riziką veikiantys veiksniai ir jų tipai, kurie nagrinejjami iš viešojo sektoriaus, finansuotojo ir investuotojo pozicijų. Rizikos veiksnių vertinimui pritaikytas kokybinis ekspertinio vertinimo metodas bei pateikiamas svarbiausių investuotojo ir finansuotojo rizikos veiksnių įvertinimas.

Raktažodžiai: rizikos valdymas, kokybinè rizikos analizè, atsinaujinanti energetika
Видмантас Янкаускас, Паулюс Рудзкис,

Адомас Канопка

\section{ФАКТОРЫ РИСКА ЗАИНТЕРЕСОВАННЫХ СТОРОН ПРИ ИНВЕСТИЦИЯХ В ВОЗОБНОВЛЯЕМЫЕ ИСТОЧНИКИ ЭНЕРГИИ}

Резюме

Современное развитие экономики основывается на инновационных идеях и новых инвестициях. Чем лучше распределение ресурсов при внедрении инвестиционных проектов, чем выше уровень инноваций, тем большую пользу получает общество. Вместе с тем и эффективность инвестиционной деятельности, и темпы экономического роста в значительной степени определяются качеством системы отбора инвестиционных проектов, которая должна отвечать существующим и изменяющимся обстоятельствам функционирования экономики. Целью статьи является идентификация и оценка факторов риска инвестиционных проектов в возобновляемой энергетике с точки зрения заинтересованных сторон. При решении этой задачи были рассмотрены методы анализа рисков, выделены факторы, влияющие на риски инвестиций в возобновляемые источники энергии, и типы этих факторов, которые рассматриваются с точек зрения общественного сектора, спонсора и инвестора. Для оценки факторов риска был использован метод качественной экспертной оценки, после чего в статье была представлена оценка важнейших факторов риска инвестора и спонсора.

Ключевые слова: управление рисками, качественный анализ рисков, возобновляемая энергетика 